\title{
Transfer of Propionibacterium innocuum Pitcher and Collins 1991 to Propioniferax gen. nov. as Propioniferax innocua comb. nov.
}

\author{
AKIRA YOKOTA, ${ }^{1 *}$ TOMOHIKO TAMURA, ${ }^{1}$ MARIKO TAKEUCHI, ${ }^{1}$ NOBERT WEISS, ${ }^{2}$ \\ AND ERKO STACKEBRANDT ${ }^{2}$ \\ Institute for Fermentation, Osaka, 17-85, Juso-honmachi, Yodogawa-ku, Osaka 532, Japan, ${ }^{1}$ and DSM-Deutsche \\ Sammlung von Mikroorganismen und Zellkulturen GmbH, D-38124 Braunschweig, Germany ${ }^{2}$
}

\begin{abstract}
$16 \mathrm{~S}$ ribosomal DNA analysis indicates that Propionibacterium innocuum is a phylogenetic neighbor of Luteococcus japonicus and that this pair of organisms branches intermediately between the genus Propionibacterium on the one side and the genera Aeromicrobium and Nocardioides on the other side. Phenotypically, strains of $P$. innocuum differ from species of Propionibacterium by exhibiting aerobic growth and possessing arabinose in the cell wall, they differ from species of Aeromicrobium and Nocardioides by the formation of propionic acid, and they differ from species of Luteococcus in morphology. Consequently, $P$. innocuum should not be classified with authentic Propionibacterium species, and the transfer of $P$. innocuum Pitcher and Collins 1991 to a new genus, Propioniferax, as Propioniferax innocua gen. nov., comb. nov. is proposed.
\end{abstract}

It has been proposed recently by Pitcher and Collins (14) that the species Propionibacterium innocuum is an LL-diaminopimelic acid (LL- $\mathrm{A}_{2} \mathrm{pm}$ )-containing coryneform bacterium. However, in contrast to the descriptions of most Propionibacterium species $(2,4)$, strains of the species Propionibacterium innocuum show aerobic and facultatively anaerobic growth, contain arabinose in cell wall hydrolysates, and do not require blood, serum, or Tween 80 for growth. 16S rRNA analysis placed Propionibacterium innocuum as a remotely related member of the genus Propionibacterium (14). However, outside reference organisms that would have shown the position of Propionibacterium innocuum in relation to other coryneform and actinomycete species were not included in the phylogenetic analysis (14). On the basis of physiological and chemotaxonomic characteristics and a 16S rRNA sequence comparison, we propose the transfer of the species Propionibacterium innocuum from the genus Propionibacterium to a new genus, Propioniferax, as Propioniferax innocua gen. nov., comb. nov.

Propionibacterium acidipropionici DSM $4900^{\mathrm{T}}$, Propionibacterium acnes DSM $1897^{\mathrm{T}}$, Propionibacterium freudenreichii DSM $20271^{\mathrm{T}}$, Propionibacterium jensenii DSM $20535^{\mathrm{T}}$, Propionibacterium propionicus DSM $43307^{\mathrm{T}}$, Propionibacterium thoenii DSM $20276^{\mathrm{T}}$, and Propionibacterium innocuum DSM $8251^{\mathrm{T}}$ (NCTC $11082^{\mathrm{T}}$ ) were obtained from the Deutsche Sammlung von Mikroorganismen und Zellkulturen $\mathrm{GmbH}$. For chemotaxonomic studies these strains were grown in tryptic soy broth $(1 \%$ casein peptone, $0.5 \%$ yeast extract, $1 \%$ sodium lactate $[\mathrm{pH} 7.0])$ at $30^{\circ} \mathrm{C}$, and cells were harvested in the stationary phase, washed twice with water, and then freeze-dried.

Production of propionic acid from glucose was determined by gas-liquid chromatography of culture supernatants following anaerobic growth in tryptic soy broth for 8 days.

Analyses of cell wall sugars (20), amino acid composition and peptidoglycan structure $(16,20)$, and lipids (9) were performed as described previously.

Comparison of $16 \mathrm{~S}$ rRNAs was carried out as follows. All sequences were obtained from the DDBJ, GenBank, and the EMBL Data Library under the following accession numbers:

\footnotetext{
* Corresponding author. Mailing address: Institute for Fermentation, Osaka, 17-85, Juso-honmachi 2-chome, Yodogawa-ku, Osaka 532, Japan. Phone: 06-300-6555. Fax: 06-300-6814.
}

Propionibacterium acidipropionici DSM 20272, X53221; Propionibacterium acnes DSM 1897 ${ }^{\mathrm{T}}$, X53218; Propionibacterium freudenreichii DSM 20271 ${ }^{\mathrm{T}}$, X53217; Propionibacterium jensenii DSM 20535 ${ }^{\mathrm{T}}$, X53219; Propionibacterium propionicus DSM $43307^{\mathrm{T}}$, X53216; Propionibacterium thoenii DSM $20276^{\mathrm{T}}$, X53220; Arthrobacter globiformis, M23411; Micrococcus luteus, M38242; Terrabacter tumescens NCIB 8914 ${ }^{\mathrm{T}}$, X53215; Sporichthya polymorpha DSM 46113, X72377; Streptomyces griseus KCTC 9080, X61478; Nocardioides fastidiosa NCIB $12713^{\mathrm{T}}$, X53189; Aeromicrobium erythreum NRRL B-3381 ${ }^{\mathrm{T}}$, M37200; Nocardioides jensenii DSM 20641 ${ }^{\mathrm{T}}$, X53214; Nocardioides luteus NCIB $11455^{\mathrm{T}}$, X53212; Nocardioides albus DSM 43109 ${ }^{\mathrm{T}}$, X53211; and Luteococcus japonicus IFO $12422^{\mathrm{T}}$, D21245. The sequences of Nocardioides simplex ATCC $6946^{\mathrm{T}}$, Bacillus subtilis 168, and Propionibacterium innocuum NCTC $11082^{\mathrm{T}}$ were taken from references 3,5 , and 14 , respectively. DNA sequences were aligned by using the ODEN system (7). Nucleotide substitution rate values were calculated (8), and a phylogenetic tree was constructed by the neighbor-joining method (15). The topology of the tree was evaluated by bootstrap analysis of the sequence data using Clustal V software (6). The search for Propionibacterium innocuum 16S ribosomal DNA (rDNA)-specific nucleotides was carried out by using the ae 2 editor included in the Ribosomal Database Project package (10).

16S rRNA sequence analysis has substantially facilitated the classification of actinomycete genera and species (17). Comparison of 16S rRNAs of authentic Propionibacterium species showed sequence similarities ranging between 94.3 and $98.8 \%$, except for Propionibacterium innocuum, for which values for similarity with other Propionibacterium species ranged between 91.7 and $93.3 \%$ (Table 1). Without the comparison of reference organisms, Propionibacterium innocuum appears to be the most distantly related member of its genus, as previously suggested by Pitcher and Collins (14). If, however, the closest relatives of the genus Propionibacterium, i.e., members of the genera Aeromicrobium and Nocardioides $(3,11)$, are included in the analyses, Propionibacterium innocuum does not branch with the propionibacteria but rather with $L$. japonicus (18) (94.5\% similarity), and this forms a separate line of descent. Propionibacterium innocuum can be characterized by 16 and 7 unique nucleotides that are not found in the $16 \mathrm{~S}$ rDNAs of species of Propionibacterium and the Aeromicrobium-Nocardioides cluster (Table 2), respectively. The $16 \mathrm{~S}$ rDNA relationship 
TABLE 1. Similarity values for the $16 \mathrm{~S}$ rDNA sequences of Propioniferax, Propionibacterium, Luteococcus, Nocardioides and Aeromicrobium species

\begin{tabular}{|c|c|c|c|c|c|c|c|c|c|c|c|c|c|c|c|c|c|c|c|}
\hline \multirow[b]{2}{*}{ Strain } & \multicolumn{19}{|c|}{ \% Similarity to: } \\
\hline & 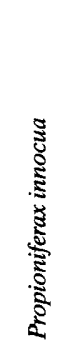 & 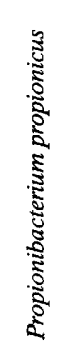 & 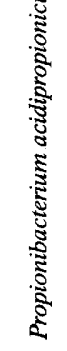 & 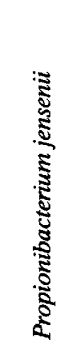 & 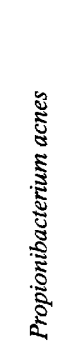 & 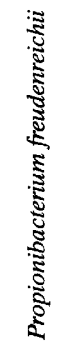 & 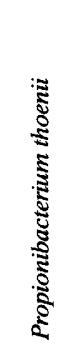 & 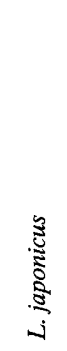 & $\begin{array}{c}\frac{3}{3} \\
\frac{3}{3} \\
z\end{array}$ & \begin{tabular}{l}
3 \\
\multirow{3}{3}{} \\
$z$ \\
$z$
\end{tabular} & 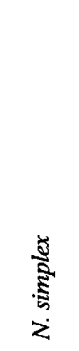 & 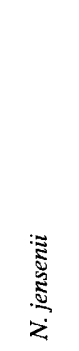 & 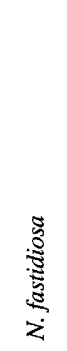 & 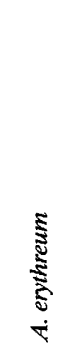 & 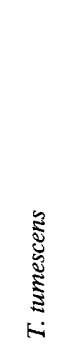 & 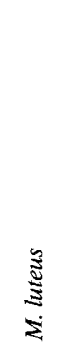 & 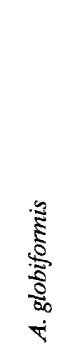 & 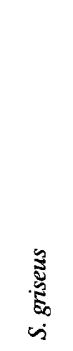 & 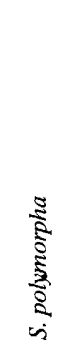 \\
\hline \multicolumn{20}{|l|}{ Propioniferax innocua } \\
\hline Propionibacterium propionicus & 93.2 & & & & & & & & & & & & & & & & & & \\
\hline Propionibacterium acidipropionici & 92.2 & 95.9 & & & & & & & & & & & & & & & & & \\
\hline Propionibacterium jensenii & 92.8 & 94.8 & 97.3 & & & & & & & & & & & & & & & & \\
\hline Propionibacterium acnes & 91.7 & 95.0 & 95.4 & 96.1 & & & & & & & & & & & & & & & \\
\hline Propionibacterium freudenreichii & 93.3 & 94.5 & 94.3 & 94.8 & 94.4 & & & & & & & & & & & & & & \\
\hline Propionibacterium thoenii & 92.7 & 95.0 & 97.3 & 98.8 & 95.7 & 94.8 & & & & & & & & & & & & & \\
\hline L. japonicus & 94.5 & 93.2 & 91.7 & 92.3 & 92.1 & 92.9 & 92.4 & & & & & & & & & & & & \\
\hline$N$. luteus & 93.2 & 92.0 & 91.8 & 92.1 & 91.2 & 91.8 & 92.3 & 93.2 & & & & & & & & & & & \\
\hline N. albus & 93.4 & 91.6 & 91.5 & 91.4 & 90.6 & 91.0 & 91.6 & 92.3 & 98.8 & & & & & & & & & & \\
\hline N. simplex & 92.9 & 92.9 & 91.6 & 92.0 & 91.8 & 92.1 & 92.3 & 92.0 & 96.7 & 96.5 & & & & & & & & & \\
\hline$N$. jensenii & 93.7 & 92.2 & 91.2 & 91.6 & 91.0 & 91.5 & 92.0 & 93.3 & 97.7 & 97.0 & 96.1 & & & & & & & & \\
\hline N. fastidiosa & 93.9 & 92.7 & 91.4 & 91.7 & 91.2 & 91.2 & 92.0 & 93.4 & 96.3 & 96.0 & 94.6 & 95.9 & & & & & & & \\
\hline A. erythreum & 93.9 & 93.2 & 92.2 & 92.3 & 91.7 & 92.4 & 92.7 & 93.4 & 95.9 & 95.3 & 94.9 & 96.0 & 98.2 & & & & & & \\
\hline T. tumescens & 92.2 & 92.2 & 91.1 & 92.1 & 91.2 & 91.8 & 92.3 & 92.8 & 93.3 & 92.7 & 93.2 & 93.5 & 92.6 & 93.2 & & & & & \\
\hline M. luteus & 91.2 & 90.7 & 90.5 & 90.9 & 89.9 & 91.1 & 91.2 & 90.7 & 92.3 & 92.4 & 92.4 & 92.4 & 92.3 & 93.2 & 94.2 & & & & \\
\hline A. globiformis & 91.1 & 91.2 & 90.1 & 90.6 & 90.3 & 90.9 & 91.0 & 90.7 & 92.1 & 92.1 & 92.7 & 91.8 & 92.3 & 92.7 & 93.9 & 97.1 & & & \\
\hline S. griseus & 90.7 & 90.9 & 89.8 & 90.1 & 89.3 & 90.7 & 90.5 & 90.6 & 91.5 & 91.0 & 90.7 & 92.0 & 91.0 & 92.2 & 92.8 & 93.1 & 92.9 & & \\
\hline S. polymorpha & 92.2 & 92.0 & 90.3 & 90.6 & 89.6 & 90.9 & 91.0 & 92.0 & 92.8 & 92.3 & 92.9 & 93.2 & 92.8 & 93.9 & 93.5 & 93.4 & 93.5 & 94.4 & \\
\hline B. subtilis & 83.7 & 82.0 & 82.2 & 82.1 & 81.5 & 82.3 & 82.0 & 83.3 & 82.8 & 82.8 & 83.4 & 83.1 & 82.7 & 83.1 & 84.7 & 84.8 & 83.9 & 84.3 & 84.8 \\
\hline
\end{tabular}

TABLE 2. 16S rDNA signature nucleotides showing the distinctness of the Propioniferax-Luteococcus cluster from the Propionibacterium and Aeromicrobium-Nocardioides lines of descent

\begin{tabular}{|c|c|c|c|}
\hline \multirow{2}{*}{$\begin{array}{l}\text { Position of } \\
\text { signature } \\
\text { nucleotide }(\mathrm{s})^{a}\end{array}$} & \multicolumn{3}{|c|}{ 16S rDNA sequence in: } \\
\hline & $\begin{array}{l}\text { Propionibacterium } \\
\text { spp. }\end{array}$ & $\begin{array}{l}\text { Propioniferax- } \\
\text { Luteococcus } \\
\text { cluster }\end{array}$ & $\begin{array}{l}\text { Aeromicrobium } \\
\text { Nocardioides } \\
\text { cluster }\end{array}$ \\
\hline $322-343$ & U-G & C-G & C-G \\
\hline 334 & $\mathrm{U}$ & $\mathbf{U}$ & $\mathrm{C}$ \\
\hline $413-441$ & $\mathrm{C}-\mathrm{G}$ & $Y-G$ & A-U \\
\hline 515 & $\mathrm{U}$ & $\mathrm{C}$ & $\mathrm{C}$ \\
\hline 598 & $\mathrm{G}$ & $\mathrm{U}$ & $\mathrm{U}$ \\
\hline $599-654$ & $A-U$ & $\mathrm{G}-\mathrm{C}$ & $\mathrm{G}-\mathrm{C}$ \\
\hline 660 & $\mathrm{U}$ & A & $\mathrm{A}(\mathrm{U})$ \\
\hline 693 & $\mathrm{G}$ & G & $\mathrm{U}$ \\
\hline 794 & C & $\mathrm{C}$ & A \\
\hline $832-859$ & A-U & A-U & G-C \\
\hline 867 & $\mathrm{U}$ & $\mathrm{C}$ & $\mathrm{C}$ \\
\hline $1006-1051$ & $\mathrm{G}-\mathrm{C}$ & A-U & $\mathrm{A}-\mathrm{U}$ \\
\hline $1129-1159$ & $A-U$ & U-A & U-A \\
\hline 1166 & $\mathrm{C}$ & $\mathbf{U}$ & $\mathrm{U}$ \\
\hline 1263 & $\mathrm{U}$ & $\mathrm{C}$ & $\mathrm{C}$ \\
\hline $1261-1290$ & $\mathrm{~A}-\mathrm{U}$ & $\mathrm{G}-\mathrm{C}$ & $\mathrm{G}-\mathrm{C}$ \\
\hline
\end{tabular}

${ }^{a}$ Position (by Escherichia coli numbering) (1) at which the 16S rDNA sequences of Propioniferax and Luteococcus have a common composition that differs from the common composition of Propionibacterium sequences and/or that of Aeromicrobium-Nocardioides cluster sequences. between Propionibacterium innocuum and $L$. japonicus is reflected by the presence of several nucleotides which they share either with propionibacteria or with members of the Aeromicrobium-Nocardioides cluster (Table 2).

As described above, Propionibacterium innocuum shares certain properties with neighboring taxa, such as peptidoglycan containing $\mathrm{LL}-\mathrm{A}_{2} \mathrm{pm}$ and glycine forming the interpeptide bridge (Propionibacterium propionicus is the only species of this group that contains a glycine residue in position 1 of the peptide subunit, whereas all other species contain alanine). Propionibacterium innocuum resembles authentic species of Propionibacterium (12) in that it contains high levels of isobranched-chain and anteiso-branched-chain compounds (iso$15: 0,22.7 \%$; iso-16:0, 12.1\%; iso-17:0, 5.9\%; anteiso-15:0, $37.3 \%$; and anteiso-17:0, 11.1\%). In contrast, members of the genera Aeromicrobium and Nocardioides are characterized by complex mixtures of straight-chain saturated, monounsaturated, and iso-branched, anteiso-branched, and 10-methylbranched fatty acids $(11,13,19)$.

Biochemically, Propionibacterium innocuum differs from Aeromicrobium species and their relatives by producing propionic acid from glucose under facultatively anaerobic conditions (at a yield of ca. $75 \%$ and with no acetic acid production), and it differs from authentic propionibacteria by its aerobic and facultatively anaerobic growth, the presence of arabinose in its cell wall hydrolysates, and the fact that it does not require blood, serum, or Tween $\mathbf{8 0}$ for growth (Table 3).

On the basis of physiological and phylogenetic data, we propose that Propionibacterium innocuum be transferred to the 
TABLE 3. Characteristics distinguishing the genera Propioniferax, Luteococcus, Propionibacterium, and the Aeromicrobium-Nocardioides cluster

\begin{tabular}{|c|c|c|c|c|}
\hline Characteristic & Propioniferax spp. & Luteococcus spp. & Propionibacterium spp. & $\begin{array}{l}\text { Aeromicrobium-Nocardioides } \\
\text { cluster }\end{array}$ \\
\hline Morphology & Rod & Coccus & Rod & Rod or hypha \\
\hline Respiration & Aerobe & Aerobe & Anaerobe & Aerobe \\
\hline $\begin{array}{l}\text { Principal cell wall neutral } \\
\text { sugars }\end{array}$ & Arabinose, mannose & Arabinose, glucose & $\begin{array}{l}\text { (Galactose), }{ }^{a} \text { (glucose), } \\
\quad \text { (rhamnose), mannose }\end{array}$ & $\begin{array}{l}\text { Galactose, (glucose), } \\
\text { (rhamnose), (mannose) }\end{array}$ \\
\hline Hydrolysis of starch & + & + & - & + \\
\hline $\begin{array}{l}\text { Formation of propionic acid } \\
\text { from glucose }\end{array}$ & + & + & + & - \\
\hline $\begin{array}{l}\text { Requirement of blood, } \\
\text { serum, or Tween } 80\end{array}$ & - & - & + & - \\
\hline \multicolumn{5}{|l|}{ Amino acid in peptidoglycan ${ }^{b}$} \\
\hline Diamino acid & $\mathrm{LL}-\mathrm{A}_{2} \mathrm{pm}$ & $\mathrm{LL}-\mathrm{A}_{2} \mathrm{pm}$ & $\begin{array}{l}\mathrm{LL}-\mathrm{A}_{2} \mathrm{pm}, \text { meso- } \mathrm{A}_{2} \mathrm{pm} \text {, } \\
\text { or Lys }\end{array}$ & $\mathrm{LL}-\mathrm{A}_{2} \mathrm{pm}$ \\
\hline Amino acid in position 1 & Gly & $\mathrm{ND}^{c}$ & Ala & Ala \\
\hline Menaquinone composition & MK- $9\left(\mathrm{H}_{4}\right)$ & MK-9(- $\left.\mathbf{H}_{4}\right)$ & MK-9 $\left(\mathrm{H}_{4}\right)$ & MK-9 $\left(\mathrm{H}_{4}\right)$ or MK-8 $\left(\mathrm{H}_{4}\right)$ \\
\hline
\end{tabular}

${ }^{a}$ Parentheses indicate that a compound may or may not be present.

${ }^{b}$ Lys, lysine; Gly, glycine; Ala, alanine.

ND, not determined.

genus Propioniferax gen. nov. as Propioniferax innocua (Pitcher and Collins) comb. nov.

The description of Propioniferax gen. nov. is taken from Pitcher and Collins (14) and our own data. Propioniferax (Pro.pi.on.i.fe'rax. M.L. n. acidum propionicum, propionic acid; L. adj. ferax, fertile; M.L. n. propioniferax, propionic acid-producing). Cells are gram-positive, non-acid fast, nonmotile, nonsporing, pleomorphic rods appearing in clusters and $\mathrm{V}$ forms. Colonies are white, shining, and convex to domed. The optimum growth temperature is approximately $37^{\circ} \mathrm{C}$. Grows at 10 and $40^{\circ} \mathrm{C}$. Facultatively anaerobic but luxuriant growth occurs aerobically (approximately 0.5 to $3 \mathrm{~mm}$ of growth on nutrient or horse blood agar at $37^{\circ} \mathrm{C}$ for 2 days). Catalase and oxidase positive. Cell wall contains LL-A $\mathrm{A}_{2} \mathrm{pm}$, arabinose, and mannose but not galactose. Glycine forms the interpeptide bridge of peptidoglycan. Mycolic acids are not present. Major fatty acids are anteiso-15:0 and iso-15:0. The major respiratory quinone is $\mathrm{MK}-9\left(\mathrm{H}_{4}\right)$. The $\mathrm{G}+\mathrm{C}$ content of the DNA is 59 to $63 \mathrm{~mol} \%$. The genus Propioniferax is a member of the Propionibacterium-Luteococcus-Aeromicrobium-Nocardioides line of descent within the radiation of the order Actinomycetales. Its phylogenetic neighbor is $L$. japonicus (Fig. 1).

The type species is Propioniferax innocua.

The description of Propioniferax innocua comb. nov. is the same as that published for Propionibacterium innocuum (Pitcher and Collins 1991) (14). innocua (in.noc'u.a. L. neut. adj. innocua, harmless.) Cells are gram-positive, non-acid fast, nonmotile, nonsporing, pleomorphic rods appearing in clusters and $\mathrm{V}$ forms. Colonies are white, shining, and convex to domed. The optimum growth temperature is approximately $37^{\circ} \mathrm{C}$. Grows at 10 and $40^{\circ} \mathrm{C}$. Facultatively anaerobic, but substantial growth occurs aerobically (approximately 0.5 to 3 $\mathrm{mm}$ of growth on nutrient or horse blood agar for 2 days). Catalase and oxidase positive. The principal carboxylic acid produced from glucose is propionic acid. Glucose, sucrose, maltose, trehalose, fructose, mannose, and glycerol are fermented. Inositol, arabinose, adonitol, salicin, erythritol, mannitol, cellobiose, dulcitol, raffinose, lactose, sorbose, sorbitol, and rhamnose are not utilized, and galactose utilization is variable. Gelatin is hydrolyzed. Growth occurs in the presence of $7.5 \% \mathrm{NaCl}$ but not in $10 \% \mathrm{NaCl}$. Reduces nitrate. Hydrolyzes urea and starch. Growth is not stimulated by Tween 80 , but Tween 80 is hydrolyzed. The following tests are negative: arginine dihydrolase, esculin hydrolysis, glutamate oxidation, arginine, lysine and ornithine decarboxylase, phenylalanine deaminase, citrate and malonate utilization, indole, $\mathrm{H}_{2} \mathrm{~S}$, and decomposition of tyrosine and xanthine.

Cell wall contains $\mathrm{LL}_{-} \mathrm{A}_{2} \mathrm{pm}$, arabinose, and mannose but not galactose. Mycolic acids are not present. The major respiratory quinone is MK-9 $\left(\mathrm{H}_{4}\right)$. The $\mathrm{G}+\mathrm{C}$ content of the DNA is $59^{\circ}$ to

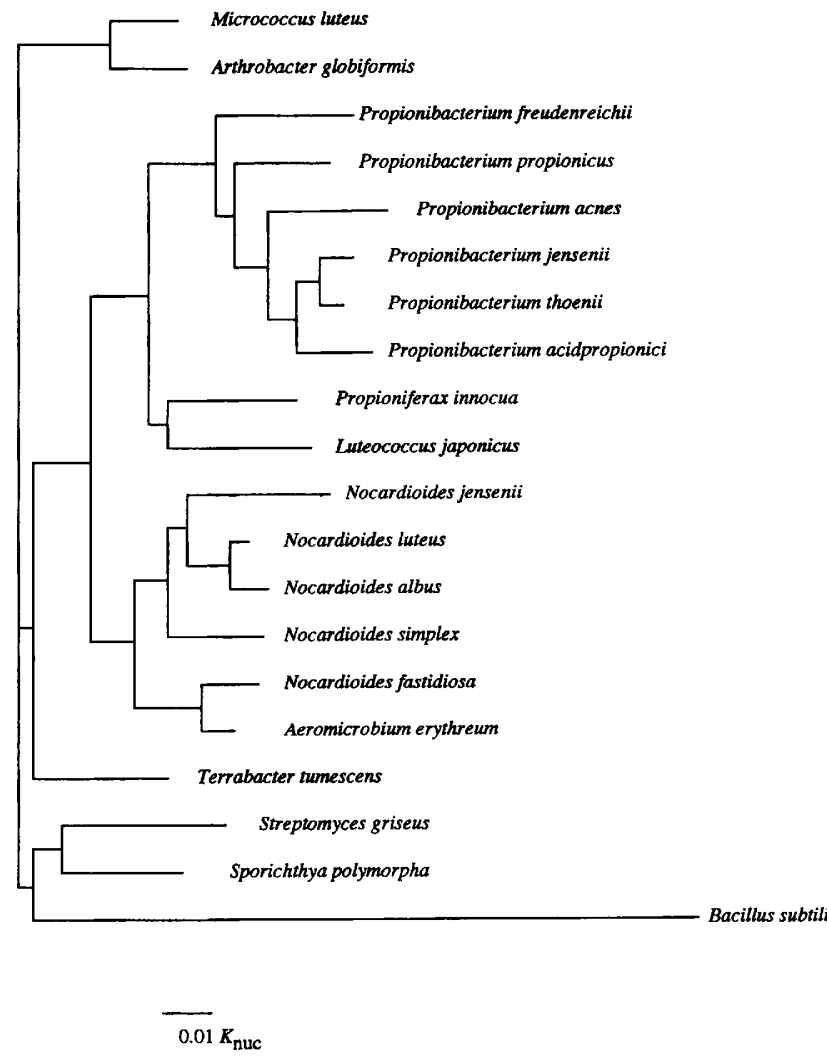

FIG. 1. Phylogenetic tree showing the relationship among Propioniferax innocua and related species. The tree was constructed by using the nucleotide substitution rate $\left(K_{\text {nuc }}\right)$ values. 
$63 \mathrm{~mol} \%$, and that of the type strain is $62 \mathrm{~mol} \%$. Habitat: human epidermal surface.

The type strain is NCTC 11082 (DSM 8251).

\section{REFERENCES}

1. Brosius, J., J. L. Palmer, J. P. Kennedy, and H. F. Noller. 1978. Complete nucleotide sequence of a 16S ribosomal RNA gene from Escherichia coli. Proc. Natl. Acad. Sci. USA 75:4801-4805.

2. Charfreitag, O., M. D. Collins, and E. Stackebrandt. 1988. Reclassification of Arachnia propionica as Propionibacterium propionicus comb. nov. Int. J. Syst. Bacteriol. 38:354-357.

3. Collins, M. D., M. Dorsch, and E. Stackebrandt. 1989. Transfer of Pimelobacter tumescens to Terrabacter gen. nov. as Terrabacter tumescens comb. nov. and of Pimelobacter jensenii to Nocardioides as Nocardioides jensenii comb. nov. Int. J. Syst. Bacteriol. 39:1-6.

4. Cummins, C. S., and J. L. Johnson. 1986. Genus I. Propionibacterium Orla-Jensen $1909,337^{\mathrm{AL}}$, p. 1346-1353. In P. H. A. Sneath, N. S. Mair, M. E. Sharpe, and J. G. Holt (ed.), Bergey's manual of systematic bacteriology, vol. 2. The Williams and Wilkins Co., Baltimore.

5. Green, C. J., G. C. Stewart, M. A. Hollis, B. S. Vold, and K. F. Bott. 1985. Nucleotide sequence of the Bacillus subtilis ribosomal RNA operon, $r m B$. Gene 37:261-266.

6. Higgins, D. R., A. J. Bleasby, and R. Fuchs. 1992. Clustal V: improved software for multiple sequence alignment. Comput. Appl. Biosci. 8:189-190.

7. Ina, Y. 1991. Molecular evolutionary analysis system for DNA and amino acid sequences (ODEN), version 1.1. DNA Data Bank of Japan, DNA Research Center, National Institute of Genetics, Mishima, Japan.

8. Kimura, M. 1980. A simple method for estimating evolutionary rates of base substitutions through comparative studies of nucleotide sequences. J. Mol. Evol. 16:111-120.

9. Kroppenstedt, R. M. 1985. Fatty acid and menaquinone analysis of actinomycetes and related organisms, p. 173-199. In M. Goodfellow and D. E. Minnikin (ed.), Chemical methods in bacterial systematics. Academic Press, London.

10. Larsen, N., G. J. Olsen, B. L. Maidak, M. J. McCaughey, R.
Overbeek, T. J. Macke, T. L. Marsh, and C. R. Woese. 1993. The ribosomal database project. Nucleic Acids Res. 21:3021-3023.

11. Miller, E. S., C. R. Woese, and S. Brenner. 1991. Description of the erythromycin-producing bacterium Arthrobacter sp. strain NRRL B-3381 as Aeromicrobium erythreum gen. nov., sp. nov. Int. J. Syst. Bacteriol. 41:363-368.

12. Moss, C. W., V. R. Dowell, D. Farshtchi, L. J. Raines, and W. B. Cherry. 1969. Cultural characteristics and fatty acid composition of propionibacteria. J. Bacteriol. 97:561-570.

13. O'Donnell, A., M. Goodfellow, and D. E. Minnikin. 1982. Lipids in the classification of Nocardioides: reclassification of Arthrobacter simplex (Jensen) Lochhead in the genus Nocardioides (Prauser) emend. O'Donnell et al. as Nocardioides simplex comb. nov. Arch. Microbiol. 133:323-329.

14. Pitcher, D. G., and M. D. Collins. 1991. Phylogenetic analysis of some LL-diaminopimelic acid-containing coryneform bacteria from human skin: description of Propionibacterium innocuum sp. nov. FEMS Microbiol. Letters 84:295-300.

15. Saitou, N., and M. Nei. 1987. The neighbor-joining method: a new method for reconstructing phylogenetic trees. Mol. Biol. Evol. 4:406-425.

16. Schleifer, K. H., and O. Kandler. 1972. Peptidoglycan types of bacterial cell walls and their taxonomic implications. Bacteriol. Rev. 36:407-477.

17. Stackebrandt, E. 1991. Aspects on the evolution and phylogeny of the actinomycetes. Actinomycetologica 5:56-63.

18. Tamura, T., M. Takeuchi, and A. Yokota. 1994. Luteococcus japonicus gen. nov., sp. nov., a new gram-positive coccus with LL-diaminopimelic acid in the cell wall. Int. J. Syst. Bacteriol. 44:348-356.

19. Yano, I., Y. Furukawa, and M. Kusunose. 1971. 2-Hydroxy fatty acid containing phospholipid of Arthrobacter simplex. Biochim. Biophys. Acta 210:105-115.

20. Yokota, A., M. Takeuchi, and N. Weiss. 1993. Proposal of two new species in the genus Microbacterium: Microbacterium dextranolyticum sp. nov. and Microbacterium aurum sp. nov. Int. J. Syst. Bacteriol. 43:549-554. 